\title{
Differences in the Resistance of Sulphate-reducing Bacteria to Inhibitors
}

\author{
By A. M. SALEH* \\ National Chemical Laboratory, Teddington, Middlesex
}

(Received 14 May 1964)

\begin{abstract}
SUMMARY
Forty-five strains of sulphate-reducing bacteria showed marked differences in their resistance to Hibitane (I.C.I. Ltd.) and, to a lesser degree, to cetyltrimethylammonium bromide. Panacide (British Drug Houses Ltd.) was effective against all the strains. The relevance of these findings to modern views on the taxonomy of the sulphate-reducers and to the problem of inhibiting these organisms in the field is discussed.
\end{abstract}

\section{INTRODUCTION}

The anaerobic sulphate-reducing bacteria are of interest both on account of their great economic importance (Postgate, 1960) and of their unique type of oxidative metabolism, which involves the utilization of sulphate or other sulphur compounds as terminal electron acceptors in place of oxygen. Numerous strains of these bacteria have now been isolated, and although few studies on their carbon sources or other aspects of their nutrition have yet been made on which a classification might be based (the feasibility of such a classification was discussed by Macpherson \& Miller, 1963), two genera and four species are now recognized on morphological and biochemical grounds: Clostridium nigrificans, Desulfovibrio desulfuricans, D. gigas (Le Gall, 1963) and $D$. orientis (Adams \& Postgate, 1959). The majority of strains isolated hitherto have been assigned to $D$. desulfuricans, a species apparently characterized by the presence of cytochrome $c_{3}$ and desulphoviridin (Postgate, 1956) though variable in $\mathrm{NaCl}$ requirement (Littlewood \& Postgate, 1957; Ochynski $\&$ Postgate, 1963), ability to dismute pyruvate (Postgate, 1952) and to metabolize choline (Baker, Papiska \& Campbell, 1962).

In a survey of the effects of inhibitors on sulphate-reducing bacteria, Saleh, Macpherson \& Miller (1964) drew attention to some marked differences in the resistance of different strains to certain inhibitors, which, though probably attributable in some cases to unstandardized experimental techniques, must in others reflect genuine physiological differences between strains. For example, in these authors' own comparative studies on the mesophile Desulfovibrio desulfuricans strain Hildenborough and the thermophilic spore-former Clostridium nigrificans strain Delft 74 $\mathrm{T}$, the thermophile proved much more susceptible to most of the inhibitors tested, growth often being suppressed by one-tenth of the concentration required to inhibit the Hildenborough strain. In the present report, the effects of four inhibitors

* Present address: Sanitary Engineering Department, Faculty of Engineering, Alexandria University, Alexandria, Egypt. 
on forty-five strains of sulphate-reducing bacteria, representative of all the four species mentioned above, were examined to discover whether there is a correlation between resistance and taxonomic position.

\section{METHODS}

Organisms. Forty-five strains of sulphate-reducing bacteria were obtained as freeze-dried ampoules from the National Collection of Industrial Bacteria (NCIB). These strains were assumed to be in pure culture; however, it is now known (Professor L. L. Campbell, personal communication) that strains Avonmouth NCIB 8398 and probably Norway 4 NCIB 8310 (Miller \& Saleh, in preparation) were mixed populations of two different types of sulphate-reducers.

The strains used, with their NCIB numbers, were as follows:

(1) Thermophiles, growth temperature 55 ${ }^{\circ}$. Strains of Clostridium nigrificans; all spore-formers; all freshwater organisms: Teddington Garden 8351; Staines G 8353; Holland cT 8356; Delft 3T 8359; Delft 15T 8361; Delft 74T 8395; unnamed strain 8706; unnamed strain 8788.

(2) Mesophiles, growth temperature $30^{\circ}$; strains 8364 and 8365 are stated (unpublished work at the National Chemical Laboratory) to grow optimally at $28^{\circ}$.

(a) Clostridium nigrificans, Coleman's strain 42 (8452). This sporulating freshwater strain, originally assigned to Desulfovibrio orientis, has now been identified as a mesophilic C. nigrificans (Postgate \& Campbell, 1963).

(b) Desulfovibrio desulfuricans -freshwater strains: Teddington м 8302, Hildenborough 8303, Wandle 8305, Essex 6 8307, Holland D-6 8311, Teddington R 8312, Beckton 8319, Holland c-6 8372, Marseille (Gaz 54) 8386, Berre Eau 8387, Berre Sol 8388, Llanelly 8446, Woolwich 8457, Byron 8458, Monticello 2 9442, 'Vibrio cholinicus' 9467; salt-water strains: El Agheila c 8308, Norway 48310 , New Jersey sw-8 8315, Venice 1 8322, Australia 8329, Canet 40 8363, California 43:63 8364, Louisiana 43:11 8365, El Agheila z 8380, Canet 20 8391, Canet 32 8392, Canet 41 8393, Walvis Bay 8397, Avonmouth 8398, British Guiana 8403, Sylt 39335 , Aberdovey (a strain recently isolated by the author) $\mathbf{9 4 9 2}$.

(c) Desulfovibrio gigas (freshwater) 9332.

(d) Desulfovibrio orientis (spore-former; freshwater) strains Singapore 18382 , Singapore 28445.

Cultivation. Cultures were raised from the freeze-dried condition at $30^{\circ}$ or $55^{\circ}$, as appropriate, in the medium of Baars (1930) containing $1.0 \mathrm{~g}$. Difco yeast extract/l. and $5 \mathrm{~mm}$-cysteine hydrochloride. $\mathrm{NaCl} 25 \mathrm{~g}$./l. was added for salt-water organisms. Details of the preparation, sterilization and $\mathrm{pH}$ adjustment of this medium are given elsewhere (Saleh et al. 1964). Stock cultures were maintained, for reasons unconnected with the present work, in the medium C of Butlin, Adams \& Thomas (1949) with additional lactate and sulphate (Dr J. R. Postgate, personal communication) and $\mathrm{NaCl}$ where necessary. All the strains grew satisfactorily in this medium and in Baars's medium; it was not found necessary to incorporate thiolacetate to ensure growth of the Desulfovibrio orientis strains (Adams \& Postgate, 1959). Subcultures were made weekly. Stock and experimental cultures were grown in Pyrex test tubes plugged with cotton-wool and incubated in McIntosh \& Fildes's anaerobic jars under an atmosphere of $99 \% \mathrm{H}_{2}+1 \% \mathrm{CO}_{2}(\mathrm{v} / \mathrm{v})$. 
Tests of inhibitors. A bacteriostatic screening method was used. Tests were carried out in Baars's medium with yeast extract and cysteine, in conformity with the practice at the National Chemical Laboratory over a number of years. Four substances known to have strong bacteriostatic or bactericidal effects on sulphate-reducers (Saleh et al. 1964) were tested against the 45 strains. These were bis-( $p$-chlorophenyl-diguanido-)hexane diacetate (Hibitane, Imperial Chemical Industries Ltd.), cetyltrimethylammonium bromide (CTAB), 5,5'-dichloro-2,2'-dihydroxy-diphenyl methane (Panacide; British Drug Houses Ltd.), and 2,4-dinitrophenol. Solutions as obtained were assumed to be sterile; CTAB and 2,4-dinitrophenol were made into concentrated solutions, allowed to stand for a few hours and assumed to be sterile. Serial dilutions were made in sterile distilled water, $2 \mathrm{ml}$. of the appropriate dilution added to $18 \mathrm{ml}$. sterile Baars's medium, and the medium adjusted when necessary to pH 7.0-7.2 (bromothymol blue) with sterile $\mathrm{NaOH}$ or $\mathrm{HCl}$. Each experimental medium was dispensed into three test tubes and inoculated with enough stock culture of the appropriate organism to give an initial concentration of between $10^{5}$ and $5 \times 10^{5}$ bacteria $/ \mathrm{ml}$. After anaerobic incubation the tubes were examined for blackening (formation of $\mathrm{FeS}$ ); cultures which showed doubtful growth were examined microscopically.

\section{RESULTS}

\section{Effects of Hibitane and $C T A B$}

Hibitane and CTAB were separately tested against the 45 strains at $0 \cdot 1,0 \cdot 25,0.5$, $1 \cdot 0,2 \cdot 5,5 \cdot 0,10,25,50,100,250,500$ and $1000 \mu \mathrm{g}$. $/ \mathrm{ml}$.(parts per million). The minimum inhibitory concentration for each strain was noted after incubation for 10 days; the results were the same after a further 20 days of incubation. The difference in the bacteriostatic concentration of Hibitane towards different strains proved to be greater than ten-thousandfold (see Table 1), and was almost as great in the case of CTAB (Table 2). In both cases the spore formers (strains of Clostridium nigrificans and Desulfovibrio orientis) were more sensitive than the non-sporulators. Hibitane was the more effective inhibitor, a greater number of strains being inhibited by a given concentration than by the same concentration of CTAB.

\section{Effects of Panacide and dinitrophenol}

These two inhibitors were tested over the range of concentrations used for Hibitane and CTAB. Tubes were examined for growth after 10 days. Panacide at $50 \mu \mathrm{g} . / \mathrm{ml}$. was effective against all the strains tested (Table 3), 2,4-dinitrophenol at $100 \mu \mathrm{g} . / \mathrm{ml}$. (Table 4), that is, a poorer separation of the strains was obtained with these two compounds. The representatives of Clostridium nigrificans and Desulfovibrio orientis were, again, more susceptible than the other strains.

\section{Viability tests}

Viability tests were made on bacteria recovered from tubes containing the minimum inhibitory concentrations of three of the inhibitors. The contents of such tubes were centrifuged aseptically for $5 \mathrm{~min}$. at about $11,000 \mathrm{~g}$ and the precipitated organisms suspended in Baars's medium, transferred to test tubes and incubated. All strains except Clostridium nigrificans 8356 and 8706 and Desulfovibrio desulfuricans $8302,8307,8311,8312,8319,8398,8446$ and 9442 had been killed by incubation for 
Table 1. The minimum concentration of Hibitane inhibitory to various strains of sulphate-reducing bacteria

Concentration of Hibitane ( $\mu \mathrm{g} . / \mathrm{ml}$.

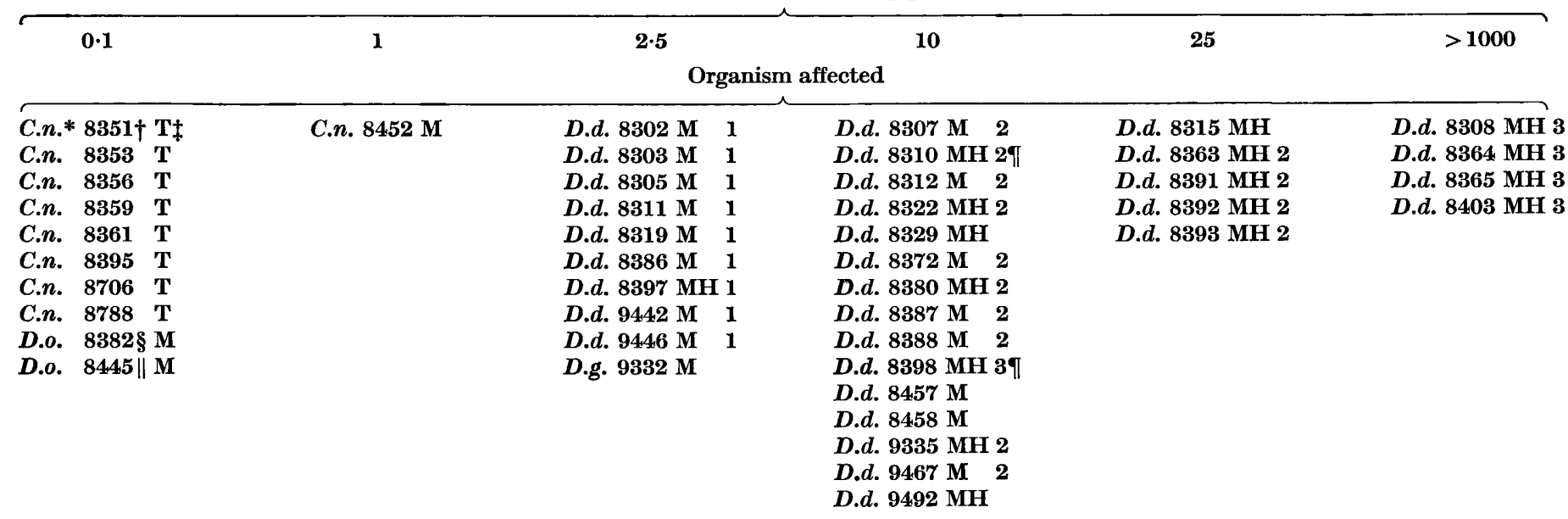

* C.n. $=$ Clostridium nigrificans; D.d. $=$ Desulfovibrio desulfuricans; D.g. $=$ D. gigas; D.o. $=$ D. orientis.

$\dagger$ NCIB number of strain.

$\ddagger \mathbf{T}=$ thermophile; $\mathbf{M}=$ mesophile $; \mathbf{H}=$ marine strain (sometimes termed 'halophilic'); $1,2,3=$ groups of $D$. desulfuricans based on DNA composition (Saunders et al. 1964).

$\S$ Inhibited by $0 \cdot 25 \mu \mathrm{g} . / \mathrm{ml}$.

|| Inhibited by $0.05 \mu \mathrm{g} . / \mathrm{ml}$.

II Mixed population: see text. 
Table 2. The minimum inhibitory concentration of CTAB towards sulphate-reducers

For explanation of symbols see Table 1.

Concentration of CTAB ( $\mu \mathrm{g} . / \mathrm{ml}$.)

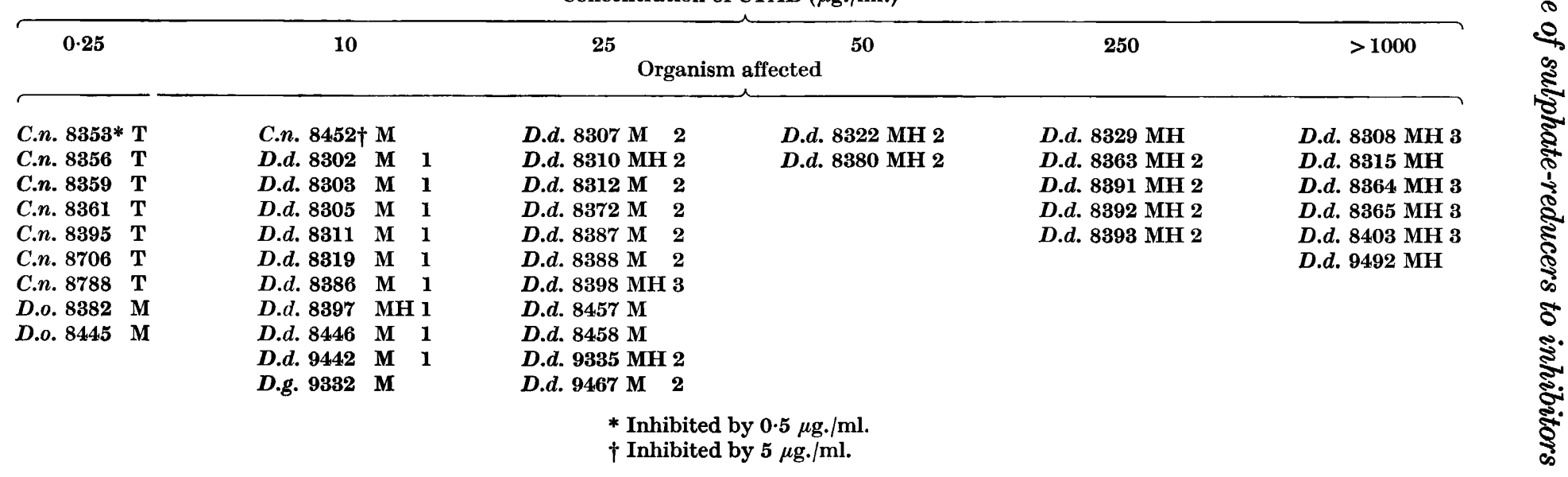


Table 3. The minimum inhibitory concentration of Panacide towards sulphate-reducers

For explanation of symbols see Table 1.

Concentration of Panacide ( $\mu \mathrm{g} . / \mathrm{ml}$.

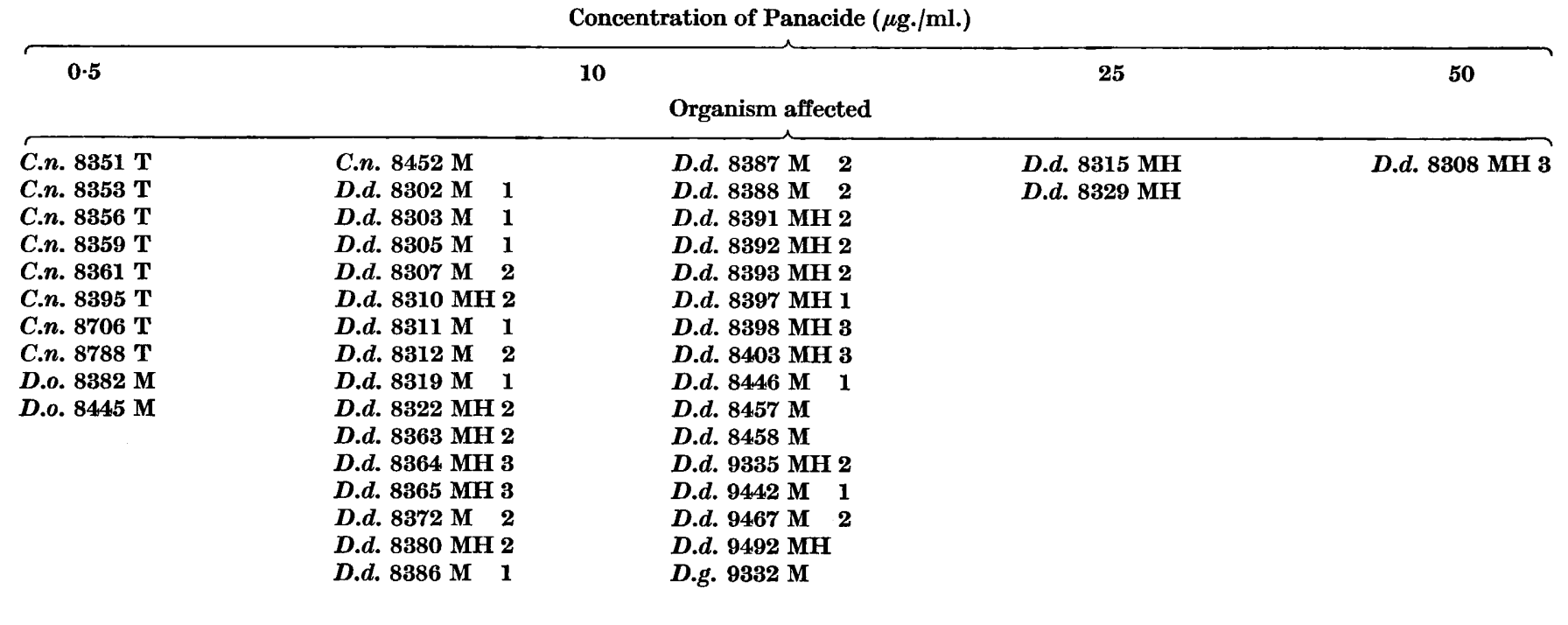


Table 4. The minimum inhibitory concentration of 2,4-dinitrophenol towards sulphate-reducers

For explanation of symbols see Table 1.

Concentration of 2,4-dinitrophenol

\begin{tabular}{|c|c|c|c|c|}
\hline $1 \cdot 0$ & 5 & $\begin{array}{l}25 \\
\text { Organism affe }\end{array}$ & 50 & 100 \\
\hline $\begin{array}{l}\text { C.n. } 8351 \mathrm{~T} \\
\text { C.n. } 8353 \mathrm{~T} \\
\text { C.n. } 8356 \mathrm{~T} \\
\text { C.n. } 8359 \mathrm{~T} \\
\text { C.n. } 8361 \mathrm{~T} \\
\text { C.n. } 8395 \mathrm{~T} \\
\text { C.n. } 8706 \mathrm{~T} \\
\text { C.n. } 8788 \mathrm{~T} \\
\text { D.o. } 8382 \mathrm{M} \\
\text { D.o. } 8445 \mathrm{M}\end{array}$ & C.n. $8452 \mathrm{M}$ & $\begin{array}{l}\text { D.d. } 8302 \mathrm{M} \\
\text { D.d. } 8303 \mathrm{M} \\
\text { D.d. } 8305 \mathrm{M} \\
\text { D.d. } 8311 \\
\text { D.d. } 8312 \mathrm{M}\end{array}$ & $\begin{array}{l}\text { D.d. } 8307 \text { M } 2 \\
\text { D.d. } 8308 \text { MH } 3 \\
\text { D.d. } 8310 \text { MH } 2 \\
\text { D.d. } 8315 \text { MH } \\
\text { D.d. } 8363 \text { MH } 2 \\
\text { D.d. } 8365 \text { MH } 3 \\
\text { D.d. } 8380 \text { MH 2 } \\
\text { D.d. } 8387 \text { M } 2 \\
\text { D.d. } 8388 \text { M } 2 \\
\text { D.d. } 8391 \text { MH } 2 \\
\text { D.d. } 8392 \text { MH } 2 \\
\text { D.d. } 8393 \text { MH } 2 \\
\text { D.d. } 8398 \text { MH } 3 \\
\text { D.d. } 8403 \text { MH } 3 \\
\text { D.d. } 9492 \text { MH }\end{array}$ & $\begin{array}{l}\text { D.d. } 8446 \text { M } 1 \\
\text { D.d. } 8457 \text { M } \\
\text { D.d. } 9467 \text { M } 2\end{array}$ \\
\hline
\end{tabular}


10 days with the minimum inhibitory concentration of Hibitane. After similar treatment with CTAB only $C$. nigrificans 8353 and $D$. orientis 8445 were viable; with Panacide no strain was viable. In all cases the minimum inhibitory concentration was bactericidal after 30 days of incubation; and in all cases twice (or 2.5 times) the minimum inhibitory concentration was bactericidal after 15 days.

\section{DISCUSSION}

Sigal, Senez, Le Gall \& Sebald (1963) determined the base composition of the DNA of seven strains of sulphate-reducing bacteria, representative of all four known species, and found significant differences which correlated with taxonomic position. Saunders, Campbell \& Postgate (1964), in a much wider survey of the species Desulfovibrio desulfuricans, recognize three groups. Group 1, with a guanine+ cytosine content of 60-62\% of the total DNA base, is composed mainly of freshwater organisms, unable to dismute pyruvate or to metabolize choline. Group 2 organisms (54-56\% guanine + cytosine) are predominantly salt-water forms, though adaptable in all cases but one to $\mathrm{NaCl}$-free medium, and are able to dismute pyruvate and metabolize choline. Members of group $3(45 \cdot 6-46 \cdot 6 \%$ guanine + cytosine) are strict salt-water strains. In the present work, the group numbers assigned by Saunders et al. to strains of $D$. desulfuricans are shown in Tables 1-4. The most striking feature was the very high resistance of group 3 organisms to Hibitane and CTAB; the only exception, strain Avonmouth (8398), is now known to be a mixture of two types, one corresponding to group 2 but the dominant organism belonging to group 3 . Members of group 2 were somewhat more resistant to these inhibitors than were group 1 strains, a partial separation of freshwater from salt-water members of group 2 being noticeable. Curiously, though in keeping with the findings of Saleh et al. (1964), the strains of $C$. nigrificans (both thermophilic and mesophilic) and of $D$. orientis, all spore-formers, were less resistant to any of these inhibitors than were strains of $\boldsymbol{D}$. desulfuricans or $\boldsymbol{D}$. gigas.

Shewan, Hodgkiss \& Liston (1954) and Shewan, Hobbs \& Hodgkiss (1960) described a simple method of differentiating common non-pathogenic pseudomonads and vibrios on the basis of their resistance to penicillin, terramycin and a vibriostatic pteridine; Callao \& Montoya (1960) differentiated four Azotobacter species on their resistance to certain dyes. The present work shows that Desulfovibrio desulfuricans group 3 strains and the spore-forming types may be unequivocally distinguished from other sulphate-reducing bacteria by their high and low resistances to Hibitane, respectively, and that within a narrower concentration range a separation of group 1 and 2 organisms may be observed. Hence resistance to inhibitors may be a useful taxonomic character within this group of bacteria.

The remarkable range of susceptibility of the sulphate-reducers to Hibitane and CTAB illustrates the importance of conducting laboratory screening tests on strains isolated from the site in which the inhibitor is to be used (Allred, Mills \& Fisher, 1954), especially when the site is a salt-water one in which Desulfovibrio desulfuricans group 3 may be present. Alternatively, strains of known group should be included in screening tests to determine the spectrum width of the inhibitor. Panacide was found in the present work to be a broad-spectrum inhibitor of sulphate-reducing bacteria, preventing the growth of all strains at $50 \mu \mathrm{g} . / \mathrm{ml}$. and all but three at $10 \mu \mathrm{g} . / \mathrm{ml}$. 
The observed bacteriostatic concentration of an inhibitor was in all cases the same on the 30th day as the 10th; thus a 10-day incubation period is probably sufficient in this type of experiment. Viability tests showed that Hibitane, CTAB and Panacide had considerable bactericidal power at their bacteriostatic concentration; the bactericidal effect of 2,4-dinitrophenol was studied by Bennett \& Bauerle (1960).

I am indebted to Dr J. D. A. Miller for his advice and helpful criticism during these investigations and the preparation of this paper; also to the members of the Microbiology Group, National Chemical Laboratory, and Dr J. R. Postgate for valuable discussions. I wish to thank the British Council for a grant which enabled this work to be carried out.

\section{REFERENCES}

Adams, M. E. \& Postgate, J. R. (1959). A new sulphate-reducing vibrio. J. gen. Microbiol. 20, 252.

Allred, R. C., Mills, T. A. \& Frsher, H. B. (1954). Bacteriological techniques applicable to the control of sulfate reducing bacteria in water flooding operations. Prod. Mon. 19 (2) 31.

BAARs, J. K. (1930). Over sulfaatreductie door bacterien. Dissertation; Delft, Holland; W. D. Meinema.

Baker, F. D., Papiska, H. R. \& Campbell, L. L. (1962). Choline fermentation by Desulfovibrio desulfuricans. J. Bact. 84, 973.

Bennett, E. O.\& Bauerle, R.H. (1960). The sensitivities of mixed populations of bacteria to inhibitors. Aust. J. biol. Sci. 13, 142.

Buturn, K. R., Adams, M. E. \& Thomas, M. (1949). The isolation and cultivation of sulphate-reducing bacteria. J. gen. Microbiol. 3, 46.

Callao, V. \& Montoya, E. (1960). The use of dyes to distinguish between species of the genus Azotobacter. J.gen. Microbiol. 22, 657.

GaLl, J. Le (1963). A new species of Desulfovibrio. J. Bact. 86, 1120.

Littlewood, D. \& Postgate, J. R. (1957). Sodium chloride and the growth of Desulphovibrio desulphuricans. J. gen. Microbiol. 17, 378.

Macpherson, R. \& Miller, J. D. A. (1963). Nutritional studies on Desulfovibrio desulfuricans using chemically defined media. J. gen. Microbiol. 31, 365.

Ochynski, F. W. \& Postgate, J. R. (1963). Some biochemical differences between fresh water and salt water strains of sulphate-reducing bacteria. In Symposium on Marine Microbiology. Ed. by C. H. Oppenheimer. Springfield, U.S.A.: C. C. Thomas.

Postgate, J. R. (1952). Growth of sulphate-reducing bacteria in sulphate-free media. Research, 5, 189.

Postgate, J. R. (1956). Cytochrome $c_{3}$ and desulphoviridin; pigments of the anaerobe Desulphovibrio desulphuricans. J. gen. Microbiol. 14, 545.

Postgate, J. R. (1960). The economic activities of sulphate-reducing bacteria. Progr. industr. Microbiol. 2, 47.

Postgate, J. R. \& Campbell, L. L. (1963). Identification of Coleman's sulfate-reducing bacterium as a mesophilic relative of Clostridium nigrificans. J. Bact. 86, 274.

Saleh, A. M., Macpererson, R. \& Miluer, J. D. A. (1964). The effect of inhibitors on sulphate-reducing bacteria: a compilation. J. appl. Bact. 87, 1073.

Saunders, G. F., Campbell, L. L. \& Postgate, J. R. (1964). Base composition of deoxyribonucleic acid of sulfate-reducing bacteria deduced from buoyant density measurements in cesium chloride. J. Bact. (in the Press).

Shewan, J. M., Hobbs, G. \& Hodgriss, W. (1960). A determinative scheme for the identification of certain genera of Gram-negative bacteria, with special reference to the Pseudomonadaceae. J. appl. Bact. 23, 379.

Shewan, J. M., Hodgkiss, W. \& Liston, J. (1954). A method for the rapid differentiation of certain non-pathogenic, asporogenous bacilli. Nature, Lond. 173, 208.

Sigal, N., Senez, J. C., Gall, J. Le \& Sebald, M. (1963). Base composition of the deoxyribonucleic acid of sulfate-reducing bacteria. J. Bact. 85, 1315. 